\title{
Review Article \\ Patterns of Microbially Driven Carbon Cycling in the Ocean: Links between Extracellular Enzymes and Microbial Communities
}

\author{
Carol Arnosti \\ Department of Marine Sciences, University of North Carolina at Chapel Hill, 3117 Venable/Murray Hall, Chapel Hill, \\ NC 27599-3300, USA
}

Correspondence should be addressed to Carol Arnosti; arnosti@email.unc.edu

Received 4 February 2014; Revised 12 June 2014; Accepted 16 June 2014; Published 26 June 2014

Academic Editor: Christos Panagiotopoulos

Copyright (C) 2014 Carol Arnosti. This is an open access article distributed under the Creative Commons Attribution License, which permits unrestricted use, distribution, and reproduction in any medium, provided the original work is properly cited.

\begin{abstract}
Heterotrophic microbial communities play a central role in the marine carbon cycle. They are active in nearly all known environments, from the surface to the deep ocean, in the sediments, and from the equator to the Poles. In order to process complex organic matter, these communities produce extracellular enzymes of the correct structural specificity to hydrolyze substrates to sizes sufficiently small for uptake. Extracellular enzymatic hydrolysis thus initiates heterotrophic carbon cycling. Our knowledge of the enzymatic capabilities of microbial communities in the ocean is still underdeveloped. Recent studies, however, suggest that there may be large-scale patterns of enzymatic function in the ocean, patterns of community function that may be connected to emerging patterns of microbial community composition. Here I review some of these large-scale contrasts in microbial enzyme activities, between high-latitude and temperate surface ocean waters, contrasts between inshore and offshore waters, changes with depth gradients in the ocean, and contrasts between the water column and underlying sediments. These contrasting patterns are set in the context of recent studies of microbial communities and patterns of microbial biogeography. Focusing on microbial community function as well as composition and potential should yield clearer understanding of the factors driving carbon cycling in the ocean.
\end{abstract}

\section{Introduction}

Organic matter remineralization by heterotrophic microbial communities is a central component of the marine carbon cycle. These communities process approximately half of all $\mathrm{CO}_{2}$ initially fixed into organic carbon by phytoplankton [1], transforming, repackaging, and respiring dissolved and particulate organic carbon (DOC and POC) and simultaneously regenerating nutrients. In benthic environments, heterotrophic microbes act as the final filter through which organic matter passes before burial, a process that removes $\mathrm{CO}_{2}$ from the atmosphere on geologic timescales [2]. The activities of heterotrophic microbial communities therefore affect marine environments on spatial scales from local to global and on timescales from minutes to millennia.

Despite the importance of microbially driven carbon cycling, the specific factors that determine the extent, rate, and location of organic matter remineralization in the ocean are poorly understood. For example, DOC, one of the largest actively cycling organic carbon reservoirs on earth [3], is operationally defined as being labile, semilabile, semirefractory, or refractory [4], based on timescales of removal in bioassays or in the ocean [5]. Information about the structural or compositional distinctions among these fractions, however, is lacking [6]. In sediments, specific organic molecules can be quantified chemically, yet they are resistant to microbial remineralization on geologic timescales [7]. Conversely, much of the organic matter in the water column and sediments that defies chemical characterization is respired by heterotrophic microbial communities $[8,9]$. The gap between our abilities to structurally characterize organic matter and microbial communities' abilities to transform organic matter is one of the central puzzles of marine organic chemistry [10].

In broad outline, however, the manner in which heterotrophic microbial communities cycle organic carbon is 
understood. For substrates, they rely on high molecular weight macromolecules such as proteins, polysaccharides, and lipid complexes produced by phytoplankton, which constitute the base of the marine food web. The Bacteria and Archaea (hereafter simply "prokaryotes") encountering these substrates must produce extracellular enzymes to hydrolyze them to sizes sufficiently small (ca $700 \mathrm{Da}$; [15]) for cellular uptake. The activities and structural specificities of these enzymes determine which substrates are hydrolyzed and can be transported into the cell, transformed, excreted, and respired and which substrates remain untouched and are transported to other areas of the ocean or buried deeply in sediments. The extracellular enzymes that initiate remineralization therefore play a central role in determining the rate and location of carbon cycling in the ocean.

The activities and structural specificities of extracellular enzymes control microbial access to carbon substrates; understanding these factors requires knowledge of the capabilities and function of microbial communities. Studies of microbial communities, however, are hampered by the fact that most marine microbes evade isolation in pure culture [16], so their individual substrate preferences are unexplored. Genetic and genomic investigations have enabled us to overcome the "cultivation bias" to some extent, yielding new perspectives on microbial community composition $[17,18]$ and on the genetic potential of single cells [19-21]. Transcriptomes have provided insight into broad patterns of genes that are active in marine microbial communities [22, 23]. Particularly for carbon cycling, however, these studies still leave major gaps, due to vast diversity of potential substrates in the ocean and our limited abilities to identify specific functional genes related to the processing of these substrates [24]. Moreover, genetic and genomic investigations alone cannot provide sufficient information, because the current state of the art is not yet sufficiently developed. Marine organisms and habitats are inadequately represented in databases on enzyme structure and function [24], and our abilities to correctly identify and annotate genes are still limited [25]. These same factors limit current efforts to identify in marine waters genes correlated with specific enzymes [26, 27]. In the field, identification of organisms that use specific substrates [28] has advanced our knowledge considerably, although the requirement for ${ }^{14} \mathrm{C}$ or ${ }^{3} \mathrm{H}$ labeling (and issues of "cross-feeding" with extended incubation times) can limit application of this approach. Deeper understanding of the interactions among specific factors, actors, and parameters controlling the transformations of high molecular weight substrates that form the bulk of marine organic matter is needed.

The importance of measuring enzyme activities in field studies, however, has long been recognized. Pioneering work used low molecular weight substrate proxies that fluoresced upon substrate hydrolysis [29-31], a technique still commonly used today. These standard measurements of enzyme activities among heterotrophic microbial communities typically use a few small substrate proxies (often MUF- $\beta$ glucose and leucine-MCA) to obtain data that frequently are extrapolated to polysaccharide and protein hydrolyzing enzymes in general [32-34]. These small substrate proxies are useful for intercomparisons among sites and studies, but they do not measure the activities of endo-acting enzymes with which heterotrophic microbes cleave substrates midchain, an essential step in hydrolysis of macromolecules [35, 36]. Moreover, the relationship between activities measured with these proxies and the hydrolysis rates and substrate specificities of enzymes that hydrolyze true polymers is often weak [37].

In order to address some of these limitations, new approaches to measure microbial enzyme activities in the field have been developed over recent years. Most have used oligo- and polymers (peptides as well as polysaccharides) of varying structure in order to investigate enzyme structural specificity and activity in the field [38, 39] (see also [40] for a recent review). In brief, these investigations have demonstrated that size alone does not necessarily limit the rate of organic matter turnover in marine systems; larger substrates can be metabolized as rapidly as their smaller components [41, 42]. Substrate structure, however, clearly makes a difference; substrates of similar size but different composition are hydrolyzed at different rates in seawater [43-48].

Microbial communities also matter; for example, some substrates that are easily hydrolyzed in the oxygenated water column in one location resist hydrolysis in another [13, 45]. Essential differences among microbial communities are therefore often missed in a standard organic geochemical perspective on organic matter degradation. Such a perspective in essence treats microbial communities as a "black box"; carbon is processed, but the specifics are hidden. From this perspective, organic matter quality is frequently considered solely from a chemical perspective, defined, for example, in terms of $\mathrm{C} / \mathrm{N}$ ratio or molar ratios of specific constituents $[49,50]$. This perspective misses the point that organic matter quality is not a constant that can be defined meaningfully solely in chemical terms. To transform and metabolize organic matter, members of a heterotrophic microbial community must sense the presence of a substrate and produce the correct extracellular enzyme(s) to hydrolyze it to sizes suitable for uptake (Figure 1). Multiple factors are then in play: substrate quantity, nature, and accessibility and also microbial capabilities and the potential to realize them under specific environmental conditions, parameters that at this time are very difficult to measure experimentally.

Recent investigations of microbial enzyme activities in marine waters and sediments suggest that there are broadscale patterns to the microbial processing of high molecular weight organic matter. Finding these patterns and pinpointing their underlying causes-opening the microbial "black box"-will require deeper understanding of the complex interactions between microbial communities and their substrates. In the next section, some of the recent work suggesting the existence of these broad patterns is reviewed, followed by a discussion of factors and actors that may be driving these patterns; an outlook for the future concludes this review. 


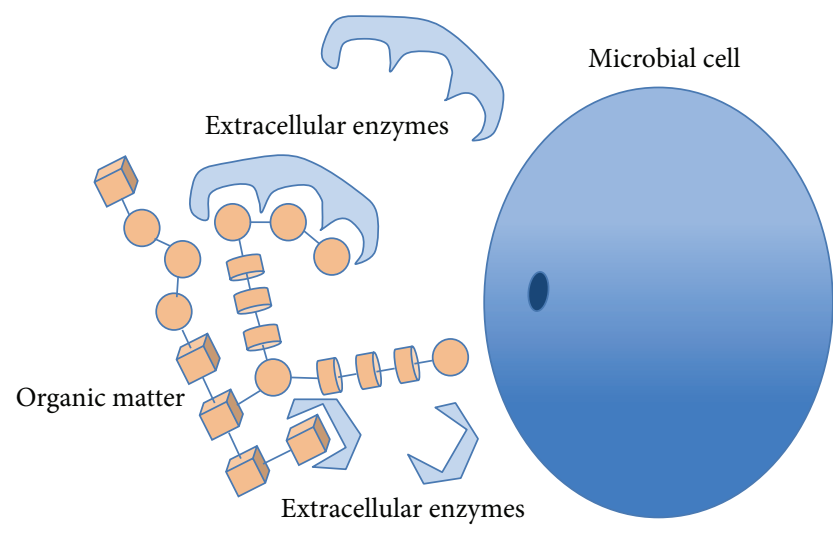

FIGURE 1: Schematic depiction of organic matter degradation by a microbial cell, which has produced endo-acting (mid-chain cleaving) and exo-acting (terminal-unit cleaving) extracellular enzymes to hydrolyze a high molecular weight substrate to sizes sufficiently small to be taken into the cell. The dark patch on the cell surface represents a microbial porin (channel for uptake of lower molecular weight hydrolysis product).

\section{Patterns of Extracellular Enzyme Activities in the Ocean}

2.1. Latitudinal Gradients in Activities of Hydrolytic Enzymes. A major pattern emerged from a decade's worth of data on polysaccharide hydrolysis in surface ocean waters, measurements of microbial enzyme activities obtained from different sites at different times, over a wide range of locations. Summed hydrolysis rates for six structurally diverse polysaccharides incubated in surface ocean waters from the Atlantic, Pacific, Arctic, and Southern Oceans showed a distinct latitudinal gradient, with the broadest spectrum (greatest number) of substrates hydrolyzed as well as the highest summed hydrolysis rates in temperate latitudes and a systematic decrease in spectrum and summed rates towards the poles (Figure 2 [13]). This latitudinal gradient extends from stations at latitudes of $79^{\circ} \mathrm{N}$ to $76^{\circ} \mathrm{S}$. The overall pattern reflects environmental temperature, but this trend is driven almost entirely by laminarin hydrolysis and by the increase in the spectrum of substrates hydrolyzed at lower latitudes. This result suggests that the ability of heterotrophic microbial communities to hydrolyze specific soluble high molecular weight substrates varies widely, and (in broad outline) systematically, in the surface ocean. Organic matter bioavailability thus depends not only on the chemically defined structural features of substrates, but also on the integrated capabilities of microbial communities.

A narrower spectrum of enzymatic capabilities among high-latitude pelagic microbial communities may apply not only for polysaccharides and phytoplankton substrates [51], but also for a wider range of organic matter. In a fjord of Svalbard, measurements of peptidase (using leucine-MCA, plus two substrates each for trypsin and chymotrypsin), glucosidase, and chitobiase activities in surface and bottom waters also demonstrated differences between surface and bottom waters [52]. Comparison of these and other data with

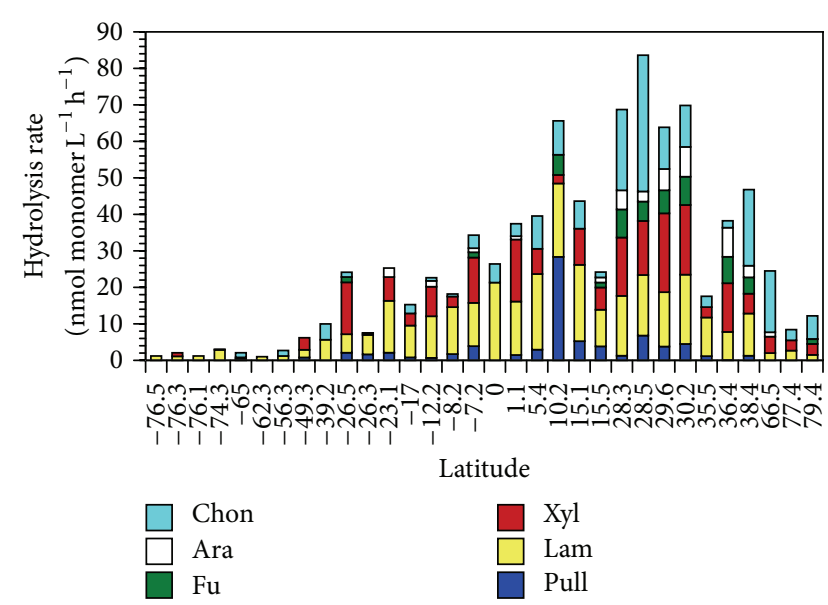

FIGURE 2: Hydrolysis rates of six structurally distinct polysaccharides in surface ocean waters of the Atlantic, Pacific, Arctic, and Southern Oceans (pull = pullulan, lam = laminarin, $x y l=$ xylan, $\mathrm{fu}=$ fucoidan, ara $=$ arabinogalactan, and chon $=$ chondroitin sulfate). Negative numbers $=$ degrees $\mathrm{S}$ latitude. The range of substrates hydrolyzed by heterotrophic microbial communities, as well as summed rates of hydrolysis, varies systematically with latitude. Only for laminarin is this variation well-correlated with in situ temperature. Microbial community function varies in a systematic manner, perhaps reflecting large-scale changes in microbial community composition along latitudinal gradients and decreased community diversity towards the poles [11, 12] (figure reprinted from [13]).

evidence from the literature $[46,47,53]$ suggests that patterns of peptide hydrolysis may differ between temperate and highlatitude sites, potentially yielding a pattern similar to that documented for polysaccharide hydrolysis.

These data suggest that surface water microbial communities may differ fundamentally in their abilities to access high molecular weight substrates, with high-latitude communities able to hydrolyze a narrower range of substrates compared to lower-latitude communities. This perspective differs somewhat from that of Kriss et al. [54] and Christian and Karl [32], who suggested that the relative activities of proteases and polysaccharide hydrolases change in opposite directions with latitude, with protein hydrolysis rates increasing at high latitude and carbohydrate hydrolysis rates increasing at lower latitudes. Kriss et al.s [54] data are based on enrichment and characterization of isolated prokaryotes, not on an assessment of entire microbial communities; Christian and Karl [32] used substrate proxies that provide no information about enzyme structural specificities. The more recent data support the hypothesis that the spectrum of substrates hydrolyzed by protein- and polysaccharide-hydrolyzing enzymes changes in the same direction with latitude; this is a novel hypothesis about enzyme function at the whole-community level.

2.2. Onshore/Offshore Gradients in Enzyme Activities. Investigations of polysaccharide hydrolase activities also point at fundamental differences between the spectrum of enzyme activities in near-shore and offshore environments. Investigations in the Chesapeake Bay and at an offshore site 
[55], in the Delaware River/Bay and an offshore site [56], and a comparison between inshore and offshore waters of North Carolina [57] generally show a narrower spectrum of substrates hydrolyzed offshore compared to inshore waters. Moreover, hydrolysis rates of individual polysaccharides are not correlated with bulk cell counts or with differences in environmental temperature [57]. Extracellular enzyme activities in the water column are thus not a simple function of bulk community or environmental parameters. Microbiological, genetic, and genomic investigations of individual microbes demonstrate that specific microbes specialize in their carbohydrate and polysaccharide substrate preferences [36, 5862 ]; these data suggest that substrate specificity extends to microbial communities as a whole.

2.3. Depth Gradients in Enzyme Activities. Studies of polysaccharide hydrolase activities to date show substantial changes in the spectrum of substrates hydrolyzed in surface and subsurface waters $[45,57,63]$, with a narrower spectrum of substrates typically hydrolyzed at depth compared to surface waters. The hydrolysis rates of individual polysaccharides, however, do not systematically decrease with depth, temperature, or cell counts, again suggesting a decoupling of enzyme activities with bulk environmental and microbial parameters. Investigations using MUF- $\alpha$ - and $\beta$-glucose and leucineMCA to measure enzyme activities along depth profiles extending to the deeper meso- and bathypelagic zones have also found that enzyme activities calculated on a per-cell basis are typically considerably higher at depth than in surface ocean waters (as reviewed in [64]), a result that also suggests depth-related differences in enzyme expression or activity.

These changes in enzyme spectrum with location and depth are intriguing in light of the fact that the structural specificities of extracellular enzymes in most of the ocean's volume, especially the deeper mesopelagic and the bathypelagic, are almost completely unknown. There are comparatively few reports in the literature of enzyme activity from the deeper meso- and bathypelagic zones (e.g., [34, 64$67]$ ); these studies used simple substrate proxies (MUF- $\alpha$ and $\beta$-glucose and leucine-MCA).

Given large contributions of Archaea to total microbial biomass at depths beyond $1000 \mathrm{~m}$ [68], genomic stratification between surface and deep waters [69], pressure-induced differences in genetic expression [70], and evidence for autotrophic processes in deep waters [71, 72], the communities targeting specific substrates may differ considerably in surface and deep ocean waters. This idea is supported by an investigation of glucose and EPS (extracellular polymeric substance) uptake in surface and deep waters of the Mediterranean Sea; in surface waters, most of the cells taking up EPS were Bacteria, but the majority of cells taking up EPS at a depth of $2000 \mathrm{~m}$ were Archaea [73]. Boutrif et al. also found that glucose assimilation decreased by several orders of magnitude between surface waters and a depth of $2000 \mathrm{~m}$, whereas EPS assimilation decreased only by ca. $35 \%$ over the same depth interval. Differences in the metabolic capabilities of surface and deep water communities are also indicated by

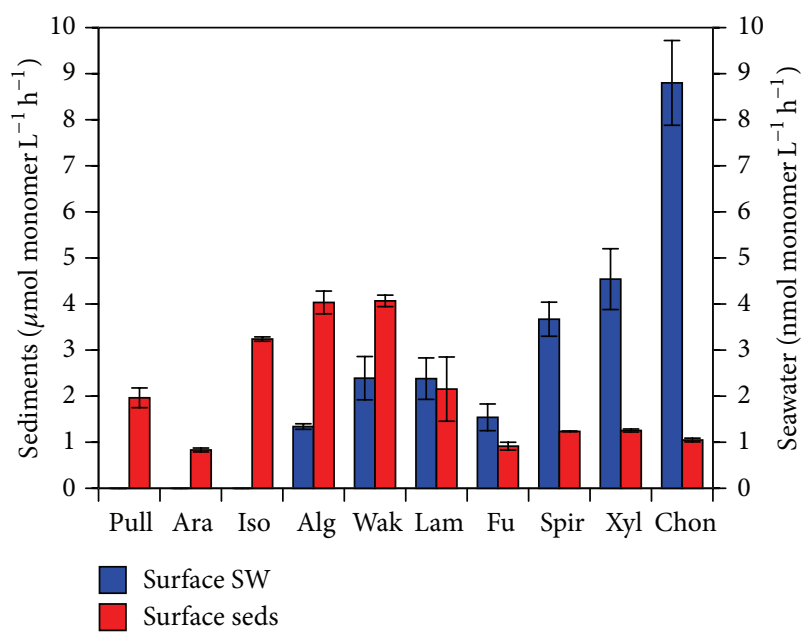

FIGURE 3: Hydrolysis rates of seven polysaccharides and three algal extracts in surface waters (blue bars, right axis) and surficial sediments (red bars, left axis) of Smeerenburgfjord, Svalbard. (pull = pullulan, ara $=$ arabinogalactan, iso $=$ Isochrysis extract, alg $=$ alginic acid, wak = wakame extract, lam = laminarin, $\mathrm{fu}=$ fucoidan, spir = Spirulina extract, $\mathrm{xyl}=$ xylan, and chon $=$ chondroitin sulfate) . All substrates were hydrolyzed in sediments, but only a subset was hydrolyzed in the water column. Note that the water column and sediment axes are offset by 3 orders of magnitude. Differences in hydrolysis patterns cannot be explained by simple scaling factors, such as differences in cell numbers. The enzymatic capabilities of these sedimentary and seawater communities are different. Data replotted from [14].

the degradation of semilabile DOC produced in the surface ocean that is then degraded in the mesopelagic ocean $[4,74]$; heterotrophic microbes at depth are capable of degrading organic matter that resists removal in the surface ocean. Mechanistic explanations for depth-stratified DOC removal processes are currently lacking [6].

2.4. Contrasting Patterns in the Water Column and Sediments. One of the most striking patterns to emerge from recent investigations of polysaccharide hydrolase activities in marine systems is the contrast between the spectrum of enzyme activities measurable in marine sediments relative to the overlying water (Figure 3). At most of the locations investigated to date, pelagic microbial communities exhibit a limited range of enzyme activities, while their benthic counterparts hydrolyze a much broader range of substrates $[14,44,51,75]$. Differences in the spectrum of substrates hydrolyzed cannot be explained simply on the basis of differences in cell abundance between benthic and pelagic environments; applying a scaling factor to account for the typical two- to three-order-of-magnitude difference in cell numbers would not create overlapping patterns of enzyme activities, as shown in Figure 3. Seven polysaccharides and three polysaccharide-containing plankton extracts were incubated in surface waters and surficial sediments from an Arctic fjord of Svalbard; all substrates were hydrolyzed in sediments, but only 7 of the 10 substrates were hydrolyzed in surface waters 
[14]. The axes for sediments and seawater hydrolysis rates in Figure 3 differ by 3 orders of magnitude, an approximation also of the difference between cell counts in the water column and typical surficial sediments. As shown in Figure 3, only rates of laminarin hydrolysis would be comparable on a per-cell basis in the water column and sediments of this fjord. Hydrolysis rates of the other substrate do not scale with cell numbers. Since only an unknown fraction of the members of microbial communities possess the capabilities to produce specific extracellular enzymes [76], this lack of correlation is likely related to differences in the abundance and activities of the subset of community members that do produce specific polysaccharide hydrolases and potentially also to the residence time of specific compounds in the water column.

\section{The Problem of Substrate Structure}

Some of these observations-the broader spectrum of enzyme activities measurable in near-shore compared to offshore locations, for example-may be linked to the diversity of natural substrates present in marine waters. Organic matter (dissolved and particulate) could be derived from terrestrial runoff, riverine inputs, and a wide range of both autochthonous and allochthonous sources; such a broad range of substrates, especially in near-shore waters, may support heterotrophic microbial communities with a broad range of enzymatic capabilities. Explicitly testing this idea requires further advances in analytical chemistry in order to desalt, isolate, and identify specific organic macromolecules from a complex matrix. Although the activities of specific extracellular enzymes can be measured in seawater and sediments, measuring the concentrations of their target substrates is not yet possible. The state of the art in marine chemistry precludes at present direct measurement of complex carbohydrates in a manner that yields sufficient structural detail to determine the nature of the enzymes that would be required for hydrolysis. Standard methods to measure marine carbohydrates $[77,78]$ typically require acid hydrolysis, which can provide accurate measurements of selected monosaccharides or of total carbohydrates, but not the information on monomer order or linkage positions. Methods such as solid-state NMR can measure bulk carbohydrates in a nondestructive manner [79] but cannot provide the structural resolution required to determine enzyme "fit." Solution-state NMR can provide key information about bond structural specificity and enzymatic hydrolysis (e.g., [80]), but only for highly purified substrates, something that has not yet been achieved for organic matter from natural environments.

\section{Patterns in Microbial Communities}

4.1. Microbial Community Composition and Function. The data presented above are consistent with the overall hypothesis that microbial community enzymatic function varies in a (relatively) systematic manner because of microbial biogeography. As discussed below, the relative influences on community function of differences in gene expression within communities versus differences in genetic potential among compositionally distinct communities remain to be ascertained. Given the diversity of enzymes produced by microbial communities and the diversity of marine microbes in the ocean, elucidating links between microbial community composition and function is difficult. Nonetheless, advances in molecular ecology, genomics, and bioinformatics are improving the research community's ability to discern patterns of microbial distribution [81-85]; metagenomic analyses provide clues to the distribution of microbial function [69, 86-88]. Microautoradiography/FISH and DNA-SIP are also proving to be important means of linking substrates and the organisms that consume them (e.g., $[89,90])$. Such approaches have been used to document major differences in substrate assimilation at different locations, for example, with Arctic surface water communities assimilating more EPS and less glucose than their temperate counterparts from the surface waters of the Delaware Estuary [91-93].

At a broad scale, the recently revealed patterns of microbial community function parallel emerging patterns in microbial biogeography. In surface marine waters, there is evidence for a latitudinal gradient in enzymatic hydrolysis rates and spectrum (Figure 2 [13]) that is not simply a reflection of in situ temperature. Latitude itself obviously drives neither hydrolysis rates nor the spectrum of enzymes active in a given location. Rather, it must function as a proxy for aspects of community function that change in broad outline in the ocean. The observed patterns in enzyme function may reflect changes in microbial community diversity along latitudinal gradients [94], including observations of decreasing community diversity at higher latitudes $[11,12$, 95]. Differences in microbial community composition have also been reported between coastal and offshore environments [96], surface and deep water environments [69, 97], and benthic and pelagic environments [98]. Beyond these individual studies, a global synthesis of data collected as part of the International Census of Marine Microbes has yielded evidence of major differences in microbial community composition (beta-diversity) between surface pelagic and deep pelagic environments, between coastal pelagic and open ocean environments, and between pelagic and benthic environments [99]. These patterns parallel in broad outline the observations to date for polysaccharide hydrolase function.

The hypothesis that differences in microbial community composition and associated changes in genetic capabilities are related to differences in enzyme function is supported by an investigation of large-particle associated microbial communities [100]. Hydrolysis rates and patterns of four substrates (chondroitin, laminarin, xylan, and fucoidan) in the $>10$ um retentate fraction isolated from near-surface waters of four oceanic provinces in the North Atlantic clustered into two groups. Similar clusters were found for microbial community structure and for metagenomic data about hydrolytic enzymes from these same stations [84, 87, 101]. Likewise, comparisons of the composition and function 
of benthic and pelagic microbial communities in a fjord of Svalbard have demonstrated that differences in community composition parallel differences in enzymatic function $[14,75]$.

4.2. Metabolic Plasticity and Functional Redundancy. One of the central challenges in explicitly linking enzymatic function with microbial diversity is to define the nature or scale of microbial diversity that correlates with functional differences [17]. The ability to produce extracellular enzymes is not evenly distributed among marine microbes [76], doubtless a factor that limits the utility of comparisons between bulk parameters (e.g., cell counts) and the activities of specific enzymes. Explicitly defining the links between community composition and function-delineating the extent of metabolic plasticity and functional redundancy among aquatic microbial communities [102] — is a major challenge, however. Metabolic plasticity and functional redundancy are interrelated but distinct; metabolic plasticity modulates microbial community function by changing gene expression and activity patterns without changing community composition, whereas functionally redundant members of a microbial community have overlapping activities and can take each other's place without compromising the overall biogeochemical function of the microbial community. For example, macroalgae-associated microbial communities differing in phylogenetic composition preserved stable genetically coded functions [103].

Plasticity and redundancy may also vary by environment. For example, at the level of the genome, organisms constituting high-latitude pelagic microbial communities may have a more limited range of genes related to hydrolytic cleavage of substrates than their more temperate counterparts. From an energetic perspective (investment in genomes versus energy yield), they may "make bets" on which substrates they are likely to encounter in the water column and specialize in those genes/enzymes to hydrolyze their most likely substrates. Breadth of function within a community may still be provided via community diversity (as suggested by our recent data from Svalbard fjords [75]), but the net effect in decreasing metabolic plasticity may be that some substrates are not accessible to major members of microbial communities, thus limiting the degree of redundancy to a point where it finally impacts community function.

The extent of metabolic plasticity and functional redundancy in microbial communities may also be influenced by parameters such as substrate availability and abundance in a specific environment. As discussed above, a wider range of potential substrate in near-shore waters may favor pelagic microbial communities equipped with enzymes suitable to hydrolyze a very diverse range of polysaccharide structures. Since possessing the genes to produce a given protein represents an energetic cost to a microbial cell, the cost/benefit balance for possessing (and producing) certain types of extracellular enzymes might then vary by environment.

Such a calculation could also help explain the oftenobserved differences between microbial communities in benthic and pelagic environments. Benthic sediments represent a concentrated accumulation of potential substrates, but acquisition of usable substrates depends on having the appropriate hydrolytic capabilities, including the capability of hydrolyzing solid (POM) substrates. A systematic examination of gene frequency and genome size of heterotrophic benthic and pelagic microbes (something that should become more tractable in the future) would provide useful information about this issue.

4.3. Responses to Changing Environmental Conditions. The enzymatic capabilities of microbial communities presumably are expressed as a flexible response to environmental conditions, which change spatially and temporally in the ocean. Microbial community dynamics-composition as well as genetic potential-also change in response [85, 86, 104]. Growth and development of phytoplankton blooms, accompanied by changes in nutrient conditions and $p \mathrm{CO}_{2}$, can lead to differential enzymatic responses among microbial communities (e.g., [105-107]). Enzymatic responses may also change under conditions of ocean acidification, as has been documented in a number of studies [108-110].

The formation and transformation of organic aggregates (marine snow) in the ocean also has a profound influence on microbial communities and on organic matter dynamics. Marine snow aggregates harbor diverse communities of microorganisms that mediate the transformations and transport of colloidal, particulate, and dissolved organic matter ([111] and references therein). Microbial dynamics in natural and laboratory-produced aggregates have shown that aggregates can be "hot spots" of carbon remineralization [112], often harboring microbial communities distinct from the surrounding water $[113,114]$. Hydrolytic activities of marine snow-attached prokaryotes can exceed those of their free-living counterparts [115-119], although some studies found no differences between free-living and attachedprokaryotic communities [120] as well as similar cellspecific hydrolytic activities in aggregates and ambient waters $[121,122]$.

Investigations with polysaccharide substrates demonstrate that the spectrum of enzyme activities that can be measured in aggregates differs from that present in surrounding seawater [123]. Some types of organic matter may therefore only be enzymatically accessible to aggregate-associated communities. Moreover, the processes of aggregate formation also shape the spectrum and relative activities of extracellular enzymes, enhancing some hydrolysis rates and leading to the production of enzymes that are freely released into the water column [124]. The nature of the aggregates themselves is also important, as has been demonstrated by investigations of oil-marine snow aggregates formed in the aftermath of the Deepwater Horizon oil spill [125]. The Deepwater Horizon oil-aggregates harbor specialized in microbial communities that likely mediate their enzymatic response [126]. In any case, the presence (as well as the nature and abundance) of aggregates in the water column might help explain temporal, spatial, and depth-related differences in the spectrum of enzyme activities observed in pelagic systems to date $[13,45,55,63,127]$. 
4.4. Aspects of Enzyme Ecological Theory. Some of the patterns in enzyme activities observed to date can be rationalized through the framework of ecological theory. In general, microbial production of extracellular enzymes should most benefit the producing organism in substrate-rich environments under conditions of restricted diffusion in which the hydrolyzed product is readily available to the producing organism $[128,129]$, that is, in sediments, on aggregates, or on particles. Higher rates of activity as well as a broader spectrum of enzyme activities in benthic compared to pelagic environments could then be interpreted as an outcome of a cost-benefit analysis, in which the "return on investment" in extracellular enzymes is greater in sediments, and therefore the extent of extracellular enzyme production is also greater. However, this framework provides little guidance in understanding the variable rates and very large differences in the spectrum of active enzymes in the marine water column (Figure $2[13,40]$ ), even in light of more complex recent models [130]. As discussed in a recent review [131], marine pelagic environments that are comparatively poor in particles and surfaces differ substantially in the spectrum and rates of enzymatic hydrolysis, differences that are not explained through current ecological theory. Moreover, cellfree enzymes have been shown to contribute substantially to total hydrolytic activity in waters of the deep ocean [66], where particles are very scarce and rates of diffusion are comparatively high. The circumstances under which organisms produce and release enzymes in marine systemsparticularly in pelagic environments-thus are not yet well understood.

\section{Microbial Extracellular Enzymes in the Ocean: Looking Forward}

The production and function of microbial extracellular enzymes is a key driver of element cycling and the focus of research in marine, freshwater, and terrestrial environments (see recent reviews: [131, 132]). In all of these environments, a major challenge is to uncover the nature and controls on the interactions between highly diverse microbial communities and their (for the most part) poorly characterized substrates.

For marine systems, the list of enticing research questions is long. Rapid developments in our ability to analyze the "-omes" of microbial communities will doubtless help push the field forward. What should not be lost in the flurry of "big data" questions, however, is the need to ground-truth the sequences and assignments with actual experimental investigations of proteins and organisms. Are our assignments of specific sequences to specific proteins accurate $[25,133]$ ? Are these proteins actually produced in the ocean, and if so, under what conditions?

In pelagic marine environments, a growing body of evidence suggests that at certain times and places a considerable fraction of the hydrolytic activity measured is due to cellfree enzymes [66, 127]. Most model considerations suggest that releasing enzymes into the environment is only an effective strategy in environments with limited diffusion, such as particles, aggregates, and sediments [129] (although a recent model of biofilm-based organisms has suggested an alternative perspective; see [134]). By what mechanisms are cell-free enzymes produced in the water column, and how long do they retain activity? One recent study suggests that at least in Arctic waters cell-free enzymes retain activity for tens of hours to several days, long enough to be spatially separated by a considerable distance from the producing organisms [135] and further complicating our efforts to link specific organisms and activities.

One of the greatest challenges to address is to determine the means by which microbial communities work in concert to degrade complex organic matter. Evidence of compositionally distinct communities that are functionally equivalent [103] provides an intriguing glimpse in this direction. Better understanding of the circumstances under which genes are exchanged among microbes [76] (and the consequences of such exchanges for community function) will help clarify this point. In any case, simply regarding microbial communities as a collection of single cells overlooks the importance of intercellular communication and interaction in the environment, whether in the form of quorum-sensing $[136,137]$ or by other means. An integrated organic geochemical perspective that includes considerations of substrate structure as well as the capabilities of complex microbial communities will be needed in order to open the microbial "black box" of carbon cycling. This focus can yield mechanistic explanations for observations of varying carbon bioavailability and utilization in diverse regions of the ocean [74], central issues for the marine carbon cycle.

\section{Conflict of Interests}

The author declares that there is no conflict of interests regarding the publication of this paper.

\section{Acknowledgments}

The author would like to thank colleagues at the University of North Carolina at Chapel Hill, as well as at the Max-Planck Institute for Marine Microbiology (Bremen, Germany), for thought-provoking discussions, productive collaborations, and intense and enjoyable fieldwork over the last several decades. Support by the Hanse Institute for Advanced Study (Delmenhorst, Germany) has greatly facilitated these collaborations. A capable, enthusiastic, and diverse group of graduate and undergraduate students at the University of North Carolina have contributed greatly to this work. In addition, Sherif Ghobrial and Kai Ziervogel have played key roles in pushing these projects forward over the last several years. Most of this work has been supported by the US National Science Foundation (most recently by OCE1332881). This work was in part also made possible by a grant from the $\mathrm{BP} /$ The Gulf of Mexico Research Initiative to support the consortium research entitled "Ecosystem Impacts of Oil and Gas Inputs to the Gulf (ECOGIG)" administered by 
the University of Mississippi. This is ECOGIG Contribution no. 257. The author also thanks four thoughtful reviewers whose comments and suggestions improved the paper.

\section{References}

[1] F. Azam and F. Malfatti, "Microbial structuring of marine ecosystems," Nature Reviews Microbiology, vol. 5, no. 10, pp. 782791, 2007.

[2] J. I. Hedges, "Global biogeochemical cycles: progress and problems," Marine Chemistry, vol. 39, no. 1-3, pp. 67-93, 1992.

[3] J. I. Hedges, "Why dissolved organics matter," in Biogeochemistry of Marine Dissolved Organic Matter, D. A. Hansell and C. A. Carlson, Eds., pp. 1-33, Academic Press, San Diego, Calif, USA, 2002.

[4] D. A. Hansell, C. A. Carlson, and R. Schlitzer, "Net removal of major marine dissolved organic carbon fractions in the subsurface ocean," Global Biogeochemical Cycles, vol. 26, no. 1, Article ID GB1016, 2012.

[5] C. A. Carlson, "Production and removal processes," in Biogeochemistry of Dissolved Organic Matter, D. A. Hansell and C. A. Carlson, Eds., pp. 91-139, Academic Press, San Diego, Calif, USA, 2002.

[6] D. A. Hansell, "Recalcitrant dissolved organic carbon fractions," Annual Review of Marine Science, vol. 5, pp. 421-445, 2013.

[7] G. L. Cowie, J. I. Hedges, F. G. Prahl, and G. J. de Lance, "Elemental and major biochemical changes across an oxidation front in a relict turbidite: an oxygen effect," Geochimica et Cosmochimica Acta, vol. 59, no. 1, pp. 33-46, 1995.

[8] C. Arnosti and M. Holmer, "Carbon cycling in a continental margin sediment: contrasts between organic matter characteristics and remineralization rates and pathways," Estuarine, Coastal and Shelf Science, vol. 58, no. 1, pp. 197-208, 2003.

[9] S. G. Wakeham, C. Lee, J. I. Hedges, P. J. Hernes, and M. L. Peterson, "Molecular indicators of diagenetic status in marine organic matter," Geochimica et Cosmochimica Acta, vol. 61, no. 24, pp. 5363-5369, 1997.

[10] C. Lee, S. Wakeham, and C. Arnosti, "Particulate organic matter in the sea: the composition conundrum," Ambio, vol. 33, no. 8, pp. 565-575, 2004.

[11] J. A. Fuhrman, J. A. Steele, I. Hewson et al., "A latitudinal diversity gradient in planktonic marine bacteria," Proceedings of the National Academy of Sciences of the United States of America, vol. 105, no. 22, pp. 7774-7778, 2008.

[12] T. Pommier, B. Canbäck, L. Riemann et al., "Global patterns of diversity and community structure in marine bacterioplankton," Molecular Ecology, vol. 16, no. 4, pp. 867-880, 2007.

[13] C. Arnosti, A. D. Steen, K. Ziervogel, S. Ghobrial, and W. H. Jeffrey, "Latitudinal gradients in degradation of marine dissolved organic carbon," PLoS ONE, vol. 6, no. 12, Article ID e28900, 2011.

[14] A. Teske, A. Durbin, K. Ziervogel, C. Cox, and C. Arnosti, "Microbial community composition and function in permanently cold seawater and sediments from an Arctic fjord of Svalbard," Applied and Environmental Microbiology, vol. 77, no. 6, pp. 2008-2018, 2011.

[15] M. S. Weiss, U. Abele, J. Weckesser, W. Welte, E. Schiltz, and G. E. Schulz, "Molecular architecture and electrostatic properties of a bacterial porin," Science, vol. 254, no. 5038, pp. 1627-1630, 1991.
[16] R. I. Amann, W. Ludwig, and K.-. Schleifer, "Phylogenetic identification and in situ detection of individual microbial cells without cultivation," Microbiological Reviews, vol. 59, no. 1, pp. 143-169, 1995.

[17] J. B. H. Martiny, B. J. M. Bohannan, J. H. Brown et al., "Microbial biogeography: putting microorganisms on the map," Nature Reviews Microbiology, vol. 4, no. 2, pp. 102-112, 2006.

[18] H. Agogué, D. Lamy, P. R. Neal, M. L. Sogin, and G. J. Herndl, "Water mass-specificity of bacterial communities in the North Atlantic revealed by massively parallel sequencing," Molecular Ecology, vol. 20, no. 2, pp. 258-274, 2011.

[19] F. M. Lauro, D. McDougald, T. Thomas et al., "The genomic basis of trophic strategy in marine bacteria," Proceedings of the National Academy of Sciences of the United States of America, vol. 106, no. 37, pp. 15527-15533, 2009.

[20] M. Martinez-Garcia, D. M. Brazel, B. K. Swan et al., "Capturing single cell genomes of active polysaccharide degraders: an unexpected contribution of verrucomicrobia," PLOS ONE, vol. 7, no. 4, Article ID e35314, 2012.

[21] R. Stepanauskas and M. E. Sieracki, "Matching phylogeny and metabolism in the uncultured marine bacteria, one cell at a time," Proceedings of the National Academy of Sciences of the United States of America, vol. 104, no. 21, pp. 9052-9057, 2007.

[22] R. S. Poretsky, S. Sun, X. Mou, and M. A. Moran, “Transporter genes expressed by coastal bacterioplankton in response to dissolved organic carbon," Environmental Microbiology, vol. 12, no. 3, pp. 616-627, 2010.

[23] Y. Shi, J. McCarren, and E. F. Delong, "Transcriptional responses of surface water marine microbial assemblages to deepsea water amendment," Environmental Microbiology, vol. 14, no. 1, pp. 191-206, 2012.

[24] E. Rebuffet, A. Groisillier, A. Thompson et al., "Discovery and structural characterization of a novel glycosidase family of marine origin," Environmental Microbiology, vol. 13, no. 5, pp. 1253-1270, 2011.

[25] F. L. Poole II, B. A. Gerwe, R. C. Hopkins et al., "Defining genes in the genome of the hyperthermophilic archaeon Pyrococcus furiosus: implications for all microbial genomes," Journal of Bacteriology, vol. 187, no. 21, pp. 7325-7332, 2005.

[26] S. Beier, C. M. Jones, V. Mohit, S. Hallin, and S. Bertilsson, "Global phylogeography of chitinase genes in aquatic metagenomes," Applied and Environmental Microbiology, vol. 77, no. 3, pp. 1101-1106, 2011.

[27] H. Elifantz, L. A. Waidner, V. K. Michelou, M. T. Cottrell, and D. L. Kirchman, "Diversity and abundance of glycosyl hydrolase family 5 in the North Atlantic Ocean," FEMS Microbiology Ecology, vol. 63, no. 3, pp. 316-327, 2008.

[28] M. T. Cottrell and D. L. Kirchman, "Natural assemblages of marine proteobacteria and members of the Cytophagaflavobacter cluster consuming low- and high-molecular-weight dissolved organic matter," Applied and Environmental Microbiology, vol. 66, no. 4, pp. 1692-1697, 2000.

[29] H.-G. Hoppe, "Significance of exoenzymatic activities in the ecology of brackish water: measurements by means of methylumbelliferyl-substrates," Marine Ecology Progress Series, vol. 11, pp. 299-308, 1983.

[30] M. Somville and G. Billen, "A method for determining exoproteolytic activity in natural waters," Limnology \& Oceanography, vol. 28, no. 1, pp. 190-193, 1983. 
[31] M. Somville, "Measurement and study of substrate specificity of exoglucosidase activity in eutrophic water," Applied and Environmental Microbiology, vol. 48, no. 6, pp. 1181-1185, 1984.

[32] J. R. Christian and D. M. Karl, "Bacterial ectoenzymes in marine waters: Activity ratios and temperature responses in three oceanographic provinces," Limnology and Oceanography, vol. 40, no. 6, pp. 1042-1049, 1995.

[33] R. Fukuda, Y. Sohrin, N. Saotome, H. Fukuda, T. Nagata, and I. Koike, "East-west gradient in ectoenzyme activities in the subarctic Pacific: possible regulation by zinc," Limnology and Oceanography, vol. 45, no. 4, pp. 930-939, 2000.

[34] R. Zaccone, A. Boldrin, G. Caruso et al., "Enzymatic activities and prokaryotic abundance in relation to organic matter along a West-East Mediterranean Transect (TRANSMED Cruise)," Microbial Ecology, vol. 64, no. 1, pp. 54-66, 2012.

[35] M. J. McBride, G. Xie, E. C. Martens et al., "Novel features of the polysaccharide-digesting gliding bacterium Flavobacterium johnsoniae as revealed by genome sequence analysis," Applied and Environmental Microbiology, vol. 75, no. 21, pp. 6864-6875, 2009.

[36] R. M. Weiner, L. E. Taylor II, B. Henrissat et al., "Complete genome sequence of the complex carbohydrate-degrading marine bacterium, Saccharophagus degradans strain 2-40 T," PLoS Genetics, vol. 4, no. 5, Article ID e1000087, 2008.

[37] R. A. J. Warren, "Microbial hydrolysis of polysaccharides," Annual Review of Microbiology, vol. 50, pp. 183-212, 1996.

[38] C. Arnosti, "Measurement of depth- and site-related differences in polysaccharide hydrolysis rates in marine sediments," Geochimica et Cosmochimica Acta, vol. 59, no. 20, pp. 4247-4257, 1995.

[39] S. Pantoja, C. Lee, and J. F. Marecek, "Hydrolysis of peptides in seawater and sediment," Marine Chemistry, vol. 57, no. 1-2, pp. 25-40, 1997.

[40] C. Arnosti, "Microbial extracellular enzymes and the marine carbon cycle," Annual Review of Marine Science, vol. 3, pp. 401425, 2011.

[41] C. Arnosti and D. J. Repeta, "Oligosaccharide degradation by anaerobic marine bacteria: characterization of an experimental system to study polymer degradation in sediments," Limnology and Oceanography, vol. 39, no. 8, pp. 1865-1877, 1994.

[42] C. Arnosti, D. J. Repeta, and N. V. Blough, "Rapid bacterial degradation of polysaccharides in anoxic marine systems," Geochimica et Cosmochimica Acta, vol. 58, no. 12, pp. 2639-2652, 1994.

[43] S. Pantoja and C. Lee, "Peptide decomposition by extracellular hydrolysis in coastal seawater and salt marsh sediment," Marine Chemistry, vol. 63, no. 3-4, pp. 273-291, 1999.

[44] C. Arnosti, "Substrate specificity in polysaccharide hydrolysis: contrasts between bottom water and sediments," Limnology and Oceanography, vol. 45, no. 5, pp. 1112-1119, 2000.

[45] C. Arnosti, S. Durkin, and W. H. Jeffrey, "Patterns of extracellular enzyme activities among pelagic marine microbial communities: implications for cycling of dissolved organic carbon," Aquatic Microbial Ecology, vol. 38, no. 2, pp. 135-145, 2005.

[46] Y. Obayashi and S. Suzuki, "Proteolytic enzymes in coastal surface seawater: significant activity of endopeptidases and exopeptidases," Limnology and Oceanography, vol. 50, no. 2, pp. 722-726, 2005.

[47] Y. Obayashi and S. Suzuki, "Occurrence of exo- and endopeptidases in dissolved and particulate fractions of coastal seawater," Aquatic Microbial Ecology, vol. 50, no. 3, pp. 231-237, 2008.
[48] Z. Liu, M. E. Kobiela, G. A. McKee et al., "The effect of chemical structure on the hydrolysis of tetrapeptides along a river-toocean transect: AVFA and SWGA," Marine Chemistry, vol. 119, no. 1-4, pp. 108-120, 2010.

[49] G. L. Cowie and J. I. Hedges, "Biochemical indicators of diagenetic alteration in natural organic matter mixtures," Nature, vol. 369, no. 6478, pp. 304-307, 1994.

[50] B. Dauwe, J. J. Middelburg, P. M. J. Herman, and C. H. R. Heip, "Linking diagenetic alteration of amino acids and bulk organic matter reactivity," Limnology and Oceanography, vol. 44, no. 7, pp. 1809-1814, 1999.

[51] C. Arnosti, "Functional differences between Arctic seawater and sedimentary microbial communities: contrasts in microbial hydrolysis of complex substrates," FEMS Microbiology Ecology, vol. 66, no. 2, pp. 343-351, 2008.

[52] A. D. Steen and C. Arnosti, "Extracellular peptidase and carbohydrate hydrolase activities in an Arctic fiord (Smeerenburgfjord, Svalbard)," Aquatic Microbial Ecology, vol. 69, no. 2, pp. 93-99, 2013.

[53] Y. Obayashi, N. Ueoka, and S. Suzuki, "Degradation and utilization of protein derived from Pseudomonas aeruginosa by marine microbial community," Journal of Oceanography, vol. 66, no. 4, pp. 513-521, 2010.

[54] A. E. Kriss, I. E. Mishustina, and E. V. Zemtsova, "Biochemical activity of micro-organisms isolated from various regions of the World Ocean," Journal of General Microbiology, vol. 29, pp. 221232, 1962.

[55] A. D. Steen, L. Hamdan, and C. Arnosti, "Dynamics of high molecular weight dissolved organic carbon in the Chesapeake Bay: insights from enzyme activities, carbohydrate concentrations, and microbial metabolism," Limnology and Oceanography, vol. 53, pp. 936-947, 2008.

[56] K. Ziervogel and C. Arnosti, "Enzyme activities in the Delaware Estuary affected by elevated suspended sediment load," Estuarine, Coastal and Shelf Science, vol. 84, no. 2, pp. 253-258, 2009.

[57] L. D’Ambrosio, K. Ziervogel, B. MacGregor, A. Teske, and C. Arnosti, "Composition and enzymatic function of particleassociated and free-living bacteria: a coastal/offshore comparison," The ISME Journal, 2014.

[58] F. O. Glöckner, M. Kube, M. Bauer et al., "Complete genome sequence of the marine planctomycete Pirellula sp. strain 1," Proceedings of the National Academy of Sciences of the United States of America, vol. 100, no. 14, pp. 8298-8303, 2003.

[59] A.-C. Alderkamp, M. Van Rijssel, and H. Bolhuis, "Characterization of marine bacteria and the activity of their enzyme systems involved in degradation of the algal storage glucan laminarin," FEMS Microbiology Ecology, vol. 59, no. 1, pp. 108117, 2007.

[60] J. A. Dodsworth, P. C. Blainey, S. K. Murugapiran et al., "Singlecell and metagenomic analyses indicate a fermentative and saccharolytic lifestyle for members of the OP9 lineage," Nature Communications, vol. 4, article 1854, 2013.

[61] D. P. R. Herlemann, D. Lundin, M. Labrenz et al., "Metagenomic de novo assembly of an aquatic representative of the verrucomicrobial class Spartobacteria," Applied and Environmental Microbiology, vol. 4, no. 3, Article ID e00569-12, 9 pages, 2013.

[62] C. Wegner, T. Richter-Heitmann, A. Klindworth et al., "Expression of sulfatases in Rhodopirellula baltica and the diversity of sulfatases in the genus Rhodopirellula," Marine Genomics, vol. 9, pp. 51-61, 2013. 
[63] A. D. Steen, K. Ziervogel, S. Ghobrial, and C. Arnosti, "Functional variation among polysaccharide-hydrolyzing microbial communities in the Gulf of Mexico," Marine Chemistry, vol. 138139, pp. 13-20, 2012.

[64] T. Nagata, C. Tamburini, J. Arístegui et al., "Emerging concepts on microbial processes in the bathypelagic ocean-ecology, biogeochemistry, and genomics," Deep-Sea Research II: Topical Studies in Oceanography, vol. 57, no. 16, pp. 1519-1536, 2010.

[65] F. Baltar, J. Arístegui, E. Sintes, H. M. van Aken, J. M. Gasol, and G. J. Herndl, "Prokaryotic extracellular enzymatic activity in relation to biomass production and respiration in the mesoand bathypelagic waters of the (sub)tropical Atlantic," Environmental Microbiology, vol. 11, no. 8, pp. 1998-2014, 2009.

[66] F. Baltar, J. Arístegui, J. M. Gasol, E. Sintes, H. M. van Aken, and G. J. Herndl, "High dissolved extracellular enzymatic activity in the deep central Atlantic ocean," Aquatic Microbial Ecology, vol. 58 , no. 3, pp. 287-302, 2010.

[67] F. Baltar, J. Arístegui, J. M. Gasol, T. Yokokawa, and G. J. Herndl, "Bacterial versus Archaeal origin of extracellular enzymatic activity in the Northeast Atlantic deep waters," Microbial Ecology, vol. 65, no. 2, pp. 277-288, 2013.

[68] M. B. Karner, E. F. Delong, and D. M. Karl, "Archaeal dominance in the mesopelagic zone of the Pacific Ocean," Nature, vol. 409, no. 6819, pp. 507-510, 2001.

[69] E. F. DeLong, C. M. Preston, T. Mincer et al., "Community genomics among stratified microbial assemblages in the ocean's interior," Science, vol. 311, no. 5760, pp. 496-503, 2006.

[70] A. Vezzi, S. Campanaro, M. D’Angelo et al., "Life at depth: photobacterium profundum genome sequence and expression analysis," Science, vol. 307, no. 5714, pp. 1459-1461, 2005.

[71] R. L. Hansman, S. Griffin, J. T. Watson et al., “The radiocarbon signature of microorganisms in the mesopelagic ocean," Proceedings of the National Academy of Sciences of the United States of America, vol. 106, no. 16, pp. 6513-6518, 2009.

[72] B. K. Swan, M. Martinez-Garcia, C. M. Preston et al., "Potential for chemolithoautotrophy among ubiquitous bacteria lineages in the dark ocean," Science, vol. 333, no. 6047, pp. 1296-1300, 2011.

[73] M. Boutrif, M. Garel, M. T. Cottrell, and C. Tamburini, "Assimilation of marine extracellular polymeric substances by deepsea prokaryotes in the NW Mediterranean Sea," Environmental Microbiology Reports, vol. 3, no. 6, pp. 705-709, 2011.

[74] C. A. Carlson, D. A. Hansell, N. B. Nelson et al., "Dissolved organic carbon export and subsequent remineralization in the mesopelagic and bathypelagic realms of the North Atlantic basin," Deep-Sea Research Part II: Topical Studies in Oceanography, vol. 57, no. 16, pp. 1433-1445, 2010.

[75] Z. Cardman, C. Arnosti, A. Durbin et al., "Verrucomicrobia: candidates for polysaccharide-degrading bacterioplankton in an Arctic fjord of Svalbard," Applied and Environmental Microbiology, vol. 80, pp. 3749-3756, 2014.

[76] A. E. Zimmerman, A. C. Martiny, and S. D. Allison, "Microdiversity of extracellular enzyme genes among sequenced prokaryotic genomes," The ISME Journal, vol. 7, no. 6, pp. 11871199, 2013.

[77] J. D. Pakulski and R. Benner, "An improved method for the hydrolysis and MBTH analysis of dissolved and particulate carbohydrates in seawater," Marine Chemistry, vol. 40, no. 3-4, pp. 143-160, 1992.
[78] C. Panagiotopoulos and R. Sempéré, "Analytical methods for the determination of sugars in marine samples: a historical perspective and future directions," Limnology and Oceanography: Methods, vol. 3, pp. 419-454, 2005.

[79] J. I. Hedges, J. A. Baldock, Y. Gélinas, C. Lee, M. Peterson, and S. G. Wakeham, "Evidence for non-selective preservation of organic matter in sinking marine particles," Nature, vol. 409, no. 6822 , pp. 801-804, 2001.

[80] C. Arnosti and D. J. Repeta, "Extracellular enzyme activity in anaerobic bacterial cultures: evidence of pullulanase activity among mesophilic marine bacteria," Applied and Environmental Microbiology, vol. 60, no. 3, pp. 840-846, 1994.

[81] J. A. Gilbert, D. Field, P. Swift et al., "The seasonal structure of microbial communities in the Western English Channel," Environmental Microbiology, vol. 11, no. 12, pp. 3132-3139, 2009.

[82] J. A. Gilbert, J. A. Steele, J. G. Caporaso et al., "Defining seasonal marine microbial community dynamics," The ISME Journal, vol. 6, no. 2, pp. 298-308, 2012.

[83] M. Schattenhofer, B. M. Fuchs, R. Amann, M. V. Zubkov, G. A. Tarran, and J. Pernthaler, "Latitudinal distribution of prokaryotic picoplankton populations in the Atlantic Ocean," Environmental Microbiology, vol. 11, no. 8, pp. 2078-2093, 2009.

[84] P. R. Gómez-Pereira, B. M. Fuchs, C. Alonso, M. J. Oliver, J. E. Van Beusekom, and R. Amann, "Distinct flavobacterial communities in contrasting water masses of the North Atlantic Ocean," ISME Journal, vol. 4, no. 4, pp. 472-487, 2010.

[85] K. L. Vergin, B. Done, C. A. Carlson, and S. J. Giovannoni, "Spatiotemporal distributions of rare bacterioplankton populations indicate adaptive strategies in the oligotrophic ocean," Aquatic Microbial Ecology, vol. 71, no. 1, pp. 1-13, 2013.

[86] J. A. Gilbert, D. Field, P. Swift et al., "The taxonomic and functional diversity of microbes at a temperate coastal site: a "multiomic" study of seasonal and diel temporal variation," PLoS ONE, vol. 5, no. 11, Article ID e15545, 2010.

[87] P. R. Gómez-Pereira, M. Schüler, B. M. Fuchs et al., “Genomic content of uncultured Bacteroidetes from contrasting oceanic provinces in the North Atlantic Ocean," Environmental Microbiology, vol. 14, no. 1, pp. 52-66, 2012.

[88] T. J. Williams, D. Wilkins, E. Long et al., “The role of planktonic Flavobacteria in processing algal organic matter in coastal East Antarctica revealed using metagenomics and metaproteomics," Environmental Microbiology, vol. 15, no. 5, pp. 1302-1317, 2013.

[89] C. E. Nelson and C. A. Carlson, "Tracking differential incorporation of dissolved organic carbon types among diverse lineages of Sargasso Sea bacterioplankton," Environmental Microbiology, vol. 14, no. 6, pp. 1500-1516, 2012.

[90] H. Sarmento and J. M. Gasol, "Use of phytoplankton-derived dissolved organic carbon by different types of bacterioplankton," Environmental Microbiology, vol. 14, no. 9, pp. 2348-2360, 2012.

[91] H. Elifantz, R. R. Malmstrom, M. T. Cottrell, and D. L. Kirchman, "Assimilation of polysaccharides and glucose by major bacterial groups in the Delaware Estuary," Applied and Environmental Microbiology, vol. 71, no. 12, pp. 7799-7805, 2005.

[92] H. Elifantz, A. I. Dittel, M. T. Cottrell, and D. L. Kirchman, "Dissolved organic matter assimilation by heterotrophic bacterial groups in the western Arctic Ocean," Aquatic Microbial Ecology, vol. 50, no. 1, pp. 39-49, 2007. 
[93] D. L. Kirchman, H. Elifantz, A. I. Dittel, R. R. Malmstrom, and M. T. Cottrell, "Standing stocks and activity of Archaea and Bacteria in the western Arctic Ocean," Limnology and Oceanography, vol. 52, no. 2, pp. 495-507, 2007.

[94] J. Ghiglione, P. E. Galand, T. Pommier et al., "Pole-to-pole biogeography of surface and deep marine bacterial communities," Proceedings of the National Academy of Sciences of the United States of America, vol. 109, no. 43, pp. 17633-17638, 2012.

[95] A. J. Baldwin, J. A. Moss, J. D. Pakulski, P. Catala, F. Joux, and W. H. Jeffrey, "Microbial diversity in a Pacific Ocean transect from the Arctic to Antarctic circles," Aquatic Microbial Ecology, vol. 41, no. 1, pp. 91-102, 2005.

[96] F. Baltar, J. Arístegui, J. M. Gasol, S. Hernández-León, and G. J. Herndl, "Strong coast-ocean and surface-depth gradients in prokaryotic assemblage structure and activity in a coastal transition zone region," Aquatic Microbial Ecology, vol. 50, no. 1, pp. 63-74, 2007.

[97] T. Yokokawa, D. de Corte, E. Sintes, and G. J. Herndl, "Spatial patterns of bacterial abundance, activity and community composition in relation to water masses in the eastern Mediterranean Sea," Aquatic Microbial Ecology, vol. 59, no. 2, pp. 185195, 2010.

[98] L. J. Hamdan, R. B. Coffin, M. Sikaroodi, J. Greinert, T. Treude, and P. M. Gillevet, "Ocean currents shape the microbiome of Arctic marine sediments," The ISME Journal, vol. 7, no. 4, pp. 685-696, 2013.

[99] L. Zinger, L. A. Amaral-Zettler, J. A. Fuhrman et al., "Global patterns of bacterial beta-diversity in seafloor and seawater ecosystems," PLoS ONE, vol. 6, no. 9, Article ID e24570, 2011.

[100] C. Arnosti, B. M. Fuchs, R. Amann, and U. Passow, "Contrasting extracellular enzyme activities of particle-associated bacteria from distinct provinces of the North Atlantic Ocean," Frontiers in Microbiology, vol. 3, article 425, 2012.

[101] M. Schattenhofer, J. Wulf, I. Kostadinov, F. O. Glöckner, M. V. Zubkov, and B. M. Fuchs, "Phylogenetic chraacterisation of picoplanktonic populatinos with high and low nucleic acid concent in the North Atlanti Ocean," Systematic and Applied Microbiology, vol. 34, pp. 470-475, 2011.

[102] J. Comte, L. Fauteux, and P. A. del Giorgio, "Links between metabolic plasticity and functional redundancy in freshwater bacterioplankton communities," Frontiers in Microbiology, vol. 4, p. 112, 2013.

[103] C. Burke, P. Steinberg, D. Rusch, S. Kjelleberg, and T. Thomas, "Bacterial community assembly based on functional genes rather than species," Proceedings of the National Academy of Sciences of the United States of America, vol. 108, no. 34, pp. 14288-14293, 2011.

[104] S. M. Hatosy, J. B. Martiny, R. Sachdeva, J. Steele, J. A. Fuhrman, and A. C. Martiny, "Beta diversity of marine bacteria depends on temporal scale," Ecology, vol. 94, pp. 1898-1904, 2013.

[105] A. E. Murray, C. Arnosti, C. L. De La Rocha, H. Grossart, and U. Passow, "Microbial dynamics in autotrophic and heterotrophic seawater mesocosms. II. Bacterioplankton community structure and hydrolytic enzyme activities," Aquatic Microbial Ecology, vol. 49, no. 2, pp. 123-141, 2007.

[106] C. Arnosti, H. P. Grossart, M. Mühling, I. Joint, and U. Passow, "Dynamics of extracellular enzyme activities in seawater under changed atmospheric $\mathrm{pCO}_{2}$ : a mesocosm investigation," Aquatic Microbial Ecology, vol. 64, no. 3, pp. 285-298, 2011.

[107] H. Teeling, B. M. Fuchs, D. Becher et al., "Substrate-controlled succession of marine bacterioplankton populations induced by a phytoplankton bloom," Science, vol. 336, no. 6081, pp. 608-611, 2012.

[108] H. P. Grossart, M. Allgaier, U. Passow, and U. Riebesell, "Testing the effect of $\mathrm{CO} 2$ concentration on the dynamics of marine heterotrophic bacterioplankton," Limnology and Oceanography, vol. 51, no. 1 I, pp. 1-11, 2006.

[109] N. Yamada and M. Suzumura, "Effects of seawater acidification on hydrolytic enzyme activities," Journal of Oceanography, vol. 66, no. 2, pp. 233-241, 2010.

[110] E. W. Maas, C. S. Law, J. A. Hall et al., "Effect of ocean acidification on bacterial abundance, activity and diversity in the Ross Sea, Antarctica," Aquatic Microbial Ecology, vol. 70, no. 1, pp. 1-15, 2013.

[111] M. Simon, H. Grossart, B. Schweitzer, and H. Ploug, "Microbial ecology of organic aggregates in aquatic ecosystems," Aquatic Microbial Ecology, vol. 28, no. 2, pp. 175-211, 2002.

[112] H. Ploug and B. B. Jørgensen, "A net-jet flow system for mass transfer and microsensor studies of sinking aggregates," Marine Ecology Progress Series, vol. 176, pp. 279-290, 1999.

[113] E. F. DeLong, D. G. Franks, and A. L. Alldredge, "Phylogenetic diversity of aggregate-attached vs. free-living marine bacterial assemblages," Limnology \& Oceanography, vol. 38, no. 5, pp. 924-934, 1993.

[114] M. M. Moeseneder, C. Winter, and G. J. Herndl, "Horizontal and vertical complexity of attached and free-living bacteria of the eastern Mediterranean Sea, determined by $16 \mathrm{~S}$ rDNA and 16S rRNA fingerprints," Limnology and Oceanography, vol. 46, no. 1, pp. 95-107, 2001.

[115] M. Karner and G. J. Herndl, "Extracellular enzymatic activity and secondary production in free-living and marine-snowassociated bacteria," Marine Biology, vol. 113, no. 2, pp. 341-347, 1992.

[116] D. C. Smith, M. Simon, A. L. Alldredge, and F. Azam, "Intense hydrolytic enzyme activity on marine aggregates and implications for rapid particle dissolution," Nature, vol. 359, no. 6391, pp. 139-142, 1992.

[117] J. Rath and G. J. Herndi, "Characteristics and diversity of $\beta$-Dglucosidase (EC 3.2.1.21) activity in marine snow," Applied and Environmental Microbiology, vol. 60, no. 3, pp. 807-813, 1994.

[118] H.-P. Grossart and H. Ploug, "Microbial degradation of organic carbon and nitrogen on diatom aggregates," Limnology and Oceanography, vol. 46, no. 2, pp. 267-277, 2001.

[119] A. Zoppini, A. Puddu, S. Fazi, M. Rosati, and P. Sist, "Extracellular enzyme activity and dynamics of bacterial community in mucilaginous aggregates of the northern Adriatic Sea," Science of the Total Environment, vol. 353, no. 1-3, pp. 270-286, 2005.

[120] J. T. Hollibaugh, P. S. Wong, and M. C. Murrell, "Similarity of particle-associated and free-living bacterial communities in northern San Francisco Bay, California," Aquatic Microbial Ecology, vol. 21, no. 2, pp. 103-114, 2000.

[121] M. Agis, M. Unanue, J. Iriberri, and G. J. Herndl, "Bacterial colonization and ectoenzymatic activity in phytoplankton-derived model particles-part II: cleavage and uptake of carbohydrates," Microbial Ecology, vol. 36, no. 1, pp. 66-74, 1998.

[122] M. Unanue, I. Azúa, J. M. Arrieta, A. Labirua-Iturburu, L. Egea, and J. Iriberri, "Bacterial colonization and ectoenzymatic activity in phytoplankton-derived model particles: cleavage of peptides and uptake of amino acids," Microbial Ecology, vol. 35, no. 2, pp. 136-146, 1998. 
[123] K. Ziervogel and C. Arnosti, "Polysaccharide hydrolysis in aggregates and free enzyme activity in aggregate-free seawater from the north-eastern Gulf of Mexico," Environmental Microbiology, vol. 10, no. 2, pp. 289-299, 2008.

[124] K. Ziervogel, A. D. Steen, and C. Arnosti, "Changes in the spectrum and rates of extracellular enzyme activities in seawater following aggregate formation," Biogeosciences, vol. 7, no. 3, pp. 1007-1017, 2010.

[125] K. Ziervogel, L. McKay, B. Rhodes et al., "Microbial activities and dissolved organic matter dynamics in oil-contaminated surface seawater from the deepwater horizon oil spill site," PLoS ONE, vol. 7, no. 4, Article ID e34816, 2012.

[126] C. Arnosti, K. Ziervogel, T. Yang, and A. Teske, "Oil-derived marine aggregates - hot spots of polysaccharide degradation by specialized bacterial communities," In Press.

[127] S. C. Keith and C. Arnosti, "Extracellular enzyme activity in a river-bay-shelf transect: variations in polysaccharide hydrolysis rates with substrate and size class," Aquatic Microbial Ecology, vol. 24, no. 3, pp. 243-253, 2001.

[128] S. D. Allison, "Cheaters, diffusion and nutrients constrain decomposition by microbial enzymes in spatially structured environments," Ecology Letters, vol. 8, no. 6, pp. 626-635, 2005.

[129] Y. A. Vetter, J. W. Deming, P. A. Jumars, and B. B. KriegerBrockett, "A predictive model of bacterial foraging by means of freely released extracellular enzymes," Microbial Ecology, vol. 36, no. 1, pp. 75-92, 1998.

[130] H. J. Folse III and S. D. Allison, "Cooperation, competition, and coalitions in enzyme-producing microbes: Social evolution and nutrient depolymerization rates," Frontiers in Microbiology, vol. 3, p. 338, 2012.

[131] C. Arnosti, C. Bell, D. L. Moorhead et al., "Extracellular enzymes in terrestrial, freshwater, and marine environments: perspectives on system variability and common research needs," Biogeochemistry, vol. 117, no. 1, pp. 5-21, 2014.

[132] R. G. Burns, J. L. DeForest, J. Marxsen et al., "Soil enzymes in a changing environment: current knowledge and future directions," Soil Biology \& Biochemistry, vol. 58, pp. 216-234, 2013.

[133] M. T. Cottrell, L. Yu, and D. L. Kirchman, "Sequence and expression analyses of Cytophaga-like hydrolases in a western arctic metagenomic library and the Sargasso Sea," Applied and Environmental Microbiology, vol. 71, no. 12, pp. 8506-8513, 2005.

[134] K. Drescher, C. D. Nadell, H. A. Stone, N. S. Wingreen, and B. L. Bassler, "Solutions to the public goods dilemma in bacterial biofilms," Current Biology, vol. 24, no. 1, pp. 50-55, 2014.

[135] A. D. Steen and C. Arnosti, "Long lifetimes of $\beta$-glucosidase, leucine aminopeptidase, and phosphatase in Arctic seawater," Marine Chemistry, vol. 123, no. 1-4, pp. 127-132, 2011.

[136] L. S. Chernin, M. K. Winson, J. M. Thompson et al., "Chitinolytic activity in Chromobacterium violaceum: substrate analysis and regulation by quorum sensing," Journal of Bacteriology, vol. 180, no. 17, pp. 4435-4441, 1998.

[137] L. Gram, H. Grossart, A. Schlingloff, and T. Kiørboe, "Possible quorum sensing in marine snow bacteria: production of acylated homoserine lactones by Roseobacter strains isolated from marine snow," Applied and Environmental Microbiology, vol. 68, no. 8, pp. 4111-4116, 2002. 

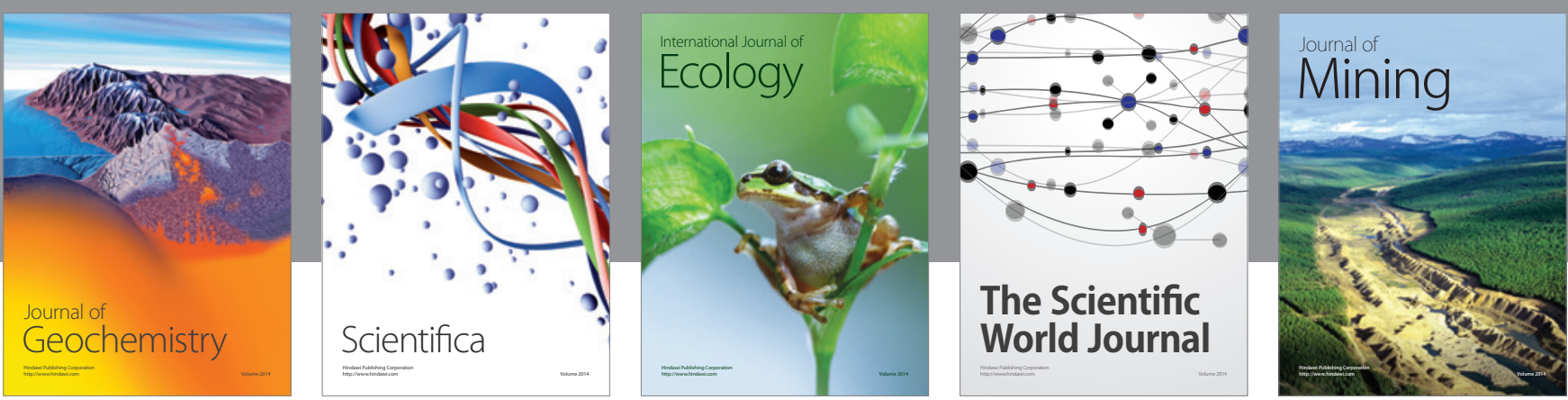

The Scientific World Journal
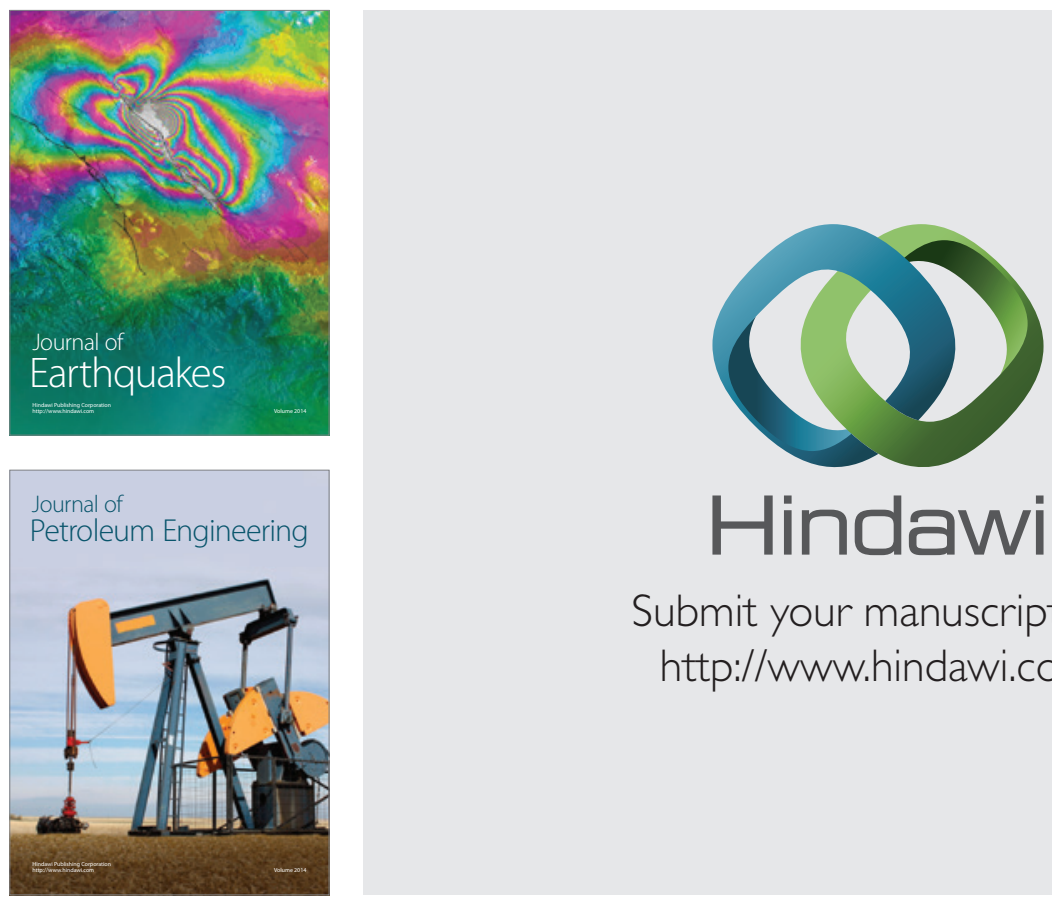

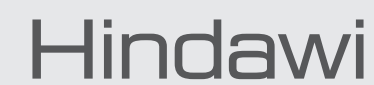

Submit your manuscripts at

http://www.hindawi.com
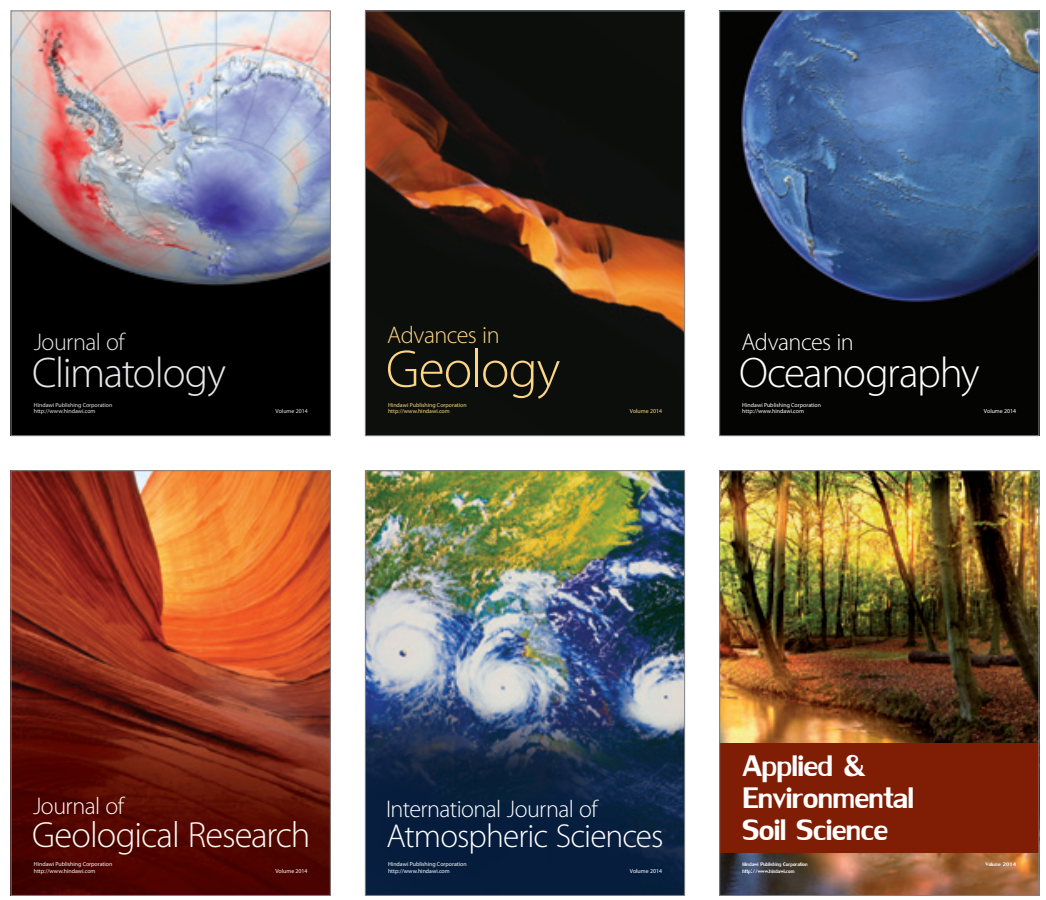
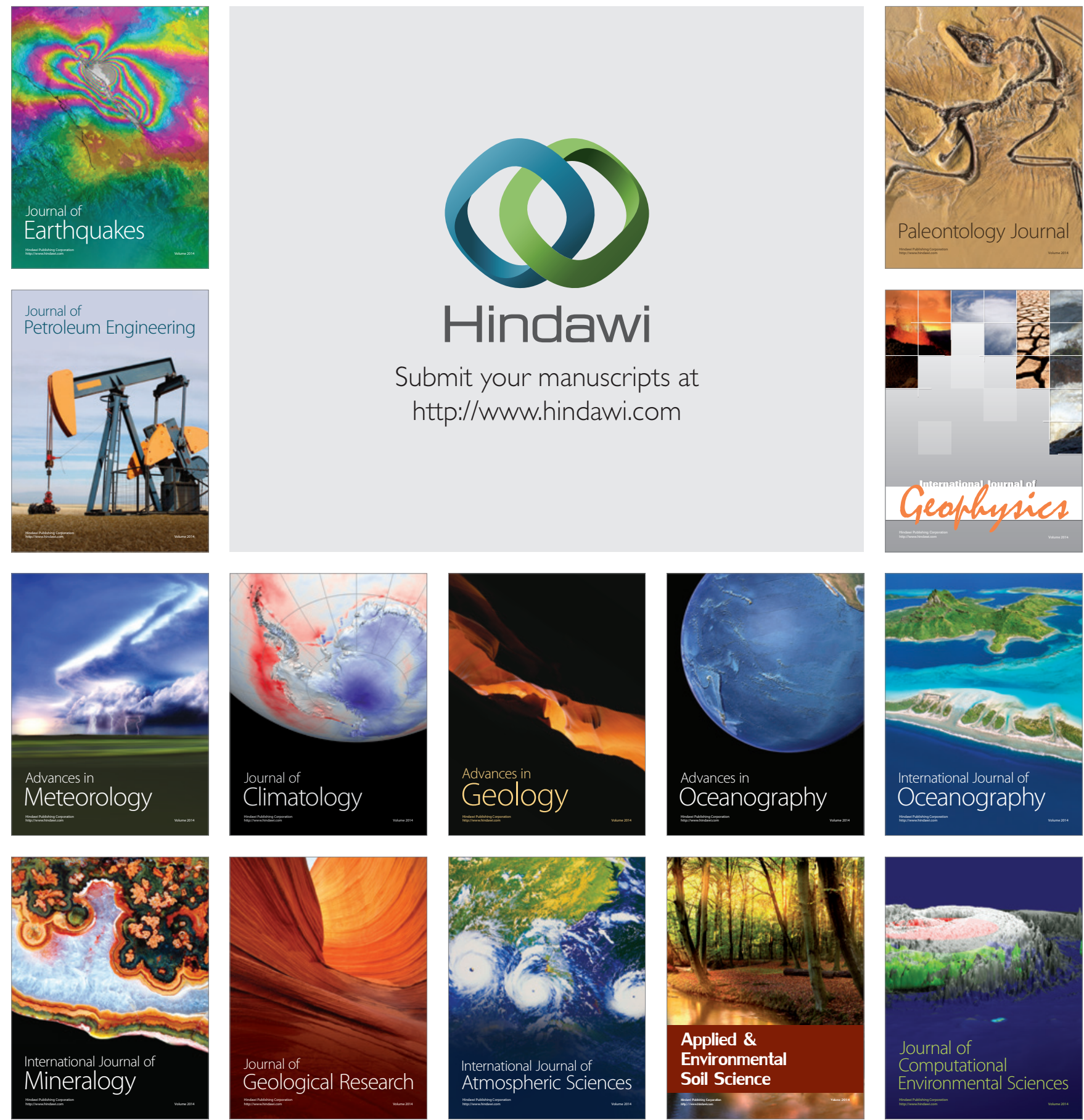